\title{
SMILE, YOU ARE ON CAMERA OR IN A LIVE TRAP! THE ROLE OF MAMMALS IN DISPERSION OF JACKFRUIT AND NATIVE SEEDS IN ILHA GRANDE STATE PARK, BRAZIL
}

\author{
Daniel S. L. Raíces ${ }^{1}$, Paula M. Ferreira², José H. F. Mello ${ }^{3}$, Helena G. Bergallo ${ }^{4}$ \\ ${ }^{1}$ Instituto Chico Mendes de Conservação da Biodiversidade, Brazil \\ e-mail:danielraices@icmbio.gov.br \\ ${ }^{2}$ Núcleo de Ecologia e Monitoramento Ambiental, Brazil \\ e-mail: paulamf84@gmail.com \\ ${ }^{3}$ Universidade Federal do Rio de Janeiro, Brazil \\ e-mail:mello.jhf@gmail.com \\ ${ }^{4}$ Universidade do Estado do Rio de Janeiro, Brazil \\ e-mail:nena.bergallo@gmail.com
}

Received: 14.08.2017

\begin{abstract}
The alien species Artocarpus heterophyllus, originally from India, was introduced to Brazil in the colonial period and has become invasive in some areas in the Atlantic Forest. Its fruits can weigh $35 \mathrm{~kg}$ and produce up to 500 seeds each. In their native range they are dispersed by turtles, rodents, monkeys, wild pigs and elephants. This study aimed to investigate the influence of mammals in jackfruit predation and seed dispersal, as well as the influence of jackfruit in native plant species dispersal by mammals, in the Ilha Grande State Park, Southeastern Brazil. Seeds with and without mesocarp were tied to thread spools and checked for predation and dispersion on 37 sites. We recorded mesocarp or jackfruit seed feeding on video. Six species of mammals were recorded feeding on jackfruit, but Trinomys dimidiatus, Didelphis aurita and Cuniculus paca accounted for $92 \%$ of all records. Cuniculus paca and Trinomys dimidiatus preyed and dispersed seeds while Didelphis aurita consumed mesocarp only. Seeds with mesocarp were more preyed on than seeds without mesocarp and its consumption was lower during more intense fruit production. Hence, jackfruit production can exceed the capacity of mammals to consume its seeds in areas where jackfruit density is high. Faeces of small mammals were collected in areas with (10 grids) and without jackfruits (8 grids) and analysed for the presence of native seeds. Twelve small mammal species were captured in areas with and without jackfruits, but faeces of 11 species were collected. Didelphis aurita dispersed proportionally more native seeds in area without jackfruits. Our results showed that mammals are playing a negative role helping to disperse jackfruit trees, and this is occurring in different ways depending on mammal species.
\end{abstract}

Key words: Artocarpus heterophyllus, Atlantic Forest, camera trap, Cuniculus paca, Didelphis aurita, fruit production, invasive alien species, Trinomys dimidiatus, seed dispersal, seed predation

\section{Introduction}

Some plant species are adapted to dispersal by specific animal groups whose dispersal syndromes are often well studied (e.g. Davidar, 1987; Mello et al., 2004). However, there are many other plant species with more general zoochoric syndromes, producing edible fruit not particularly adapted for specific animal groups or guilds (Galetti et al., 2003). These "generalist" plant species account for the majority of animal-plant interactions in ecological networks, polarising interactions within communities and greatly affecting community structure (Olesen et al., 2002; Aizen et al., 2008).

Many features such as high fruit production, efficiency in propagule dispersal and competitive interactions with local species seem to be pervasive among invasive alien plants (Rejmanék \& Richardson, 1996; Williamson \& Fitter, 1996a; 1996b). Plant species pollinated by animals or bearing fleshy fruit that attract more dispersers are invasive in numbers above average (Rejmanék \& Richardson, 1996) as animal species act as invasion facilitators. These alien species traits add to characteristics of invaded sites and unpredictable events such as localised natural disturbance in vegetation (D'Antonio \& Vitousek, 1992; Davis et al., 2000) which also facilitate invasions. These animal-plant interactions are not indefinitely stable in time but the dynamic result of community eco-evolutionary history. For example, Janzen \& Martin (1982), while studying anachronic fruit in Costa Rica - fruits apparently adapted to past environmental conditions and possibly dispersed by ancient megafauna - suggested that secondary dispersal might have played a central role in the survival of these plant species even after their main dispersers disappeared ten thousand years ago. As a result, previously non-specialised seed predator 
or secondary disperser animal species have become primary dispersers. Another case is that of jatobá trees (Hymenaea spp.) currently dispersed by agouti rodents (Dasyprocta spp., Galetti, 2004) which bury seeds in the soil for later consumption but fail to recover all stocked seeds. Consequently, some of the stored seeds are likely to germinate and settle at considerable distances from their progenitors (Galetti et al., 2006). Most mammalian species found in Brazil are small non-volant species in the orders Didelphimorphia and Rodentia, both of which may function as seed dispersers and seed predators (Vieira et al., 2003). An example of how dispersal dynamics may be influenced by other ecological interactions is presented by Asquith et al. (1997) who demonstrated that in the absence of top chain predators in Panamanian moist forests granivore density increases, negatively affecting seedling recruitment. It is also important to note that other interactions - such as predation and parasitism - constantly act as limiting factors of a given community (Prenter et al., 2004). For example, according to the enemy release hypothesis one of the reasons for invasion success is that introduced species colonise new environments that do not share their co-evolutionary history (DeWalt et al., 2004). Therefore, since pathogens and specialised herbivores acting as a natural population growth control in the native range are not present, invasive plant species would be free to redirect resources that would otherwise be used in defense mechanisms to reproductive structures (Keane \& Crawley, 2002). Consequently, compared to native plant species under control by natural enemies, a larger proportion of propagules would be able to survive (Keane \& Crawley, 2002). Janzen (1970, also Connell, 1971) found that pathogens and specialised seed predators bring about high mortality rates where propagule density is higher, usually in the immediate vicinity of the mother-plant. In Brazil, Artocarpus heterophyllus Lam. - the jackfruit tree - seems to have overcome all environmental and biological filters becoming an invasive species free of natural enemies.

Artocarpus heterophyllus (Moraceae) is native to India where its main dispersers are tortoises, rodents, primates, wild hogs (Vijaya 1982 apud Corlett 1998; Khan, 2004) and elephants (Godagama et al., 1999, Jothish, 2013). Artocarpus heterophyllus produces fruits which may weigh up to $35 \mathrm{~kg}$ and generate 500 seeds. It has an invasive status in French Polynesia, Venezuela (Ojasti et al., 2001), and Brazil, where it was intentionally introduced in the early $19^{\text {th }}$ century (Zenni \& Ziller, 2011). Nowadays, jackfruit is one of the most conspicuous invasive plants in Brazil even in protected areas (Abreu \& Rodrigues 2010, Bergallo et al. 2016). Jackfruit affects native plants by allelopathic action, and its intense use by humans and other animals may have facilitated its spread (Bergallo et al., 2016).

In this study, we have assessed the role of mammal species as predators and dispersers of A. heterophyllus and native seeds in Ilha Grande State Park, an island off the Rio de Janeiro State coast. Our objectives were to (1) determine which mammals are predators and which are dispersers of jackfruit and native seeds; (2) verify whether there are differences between predation of seeds with and without mesocarp; (3) determine seed dispersal distance by mammals; (4) determine whether the number of preyed and non-preyed jackfruit seeds is dependent on the number of fruit-producing trees; and (5) determine whether there are differences in the amount of seeds dispersed by small mammals in areas with different jackfruit densities.

\section{Methods}

\section{Study area}

This study was carried out at Ilha Grande State Park on an island on the southeastern coast of Rio de Janeiro state, Brazil $\left(23^{\circ} 5^{\prime} 2.01^{\prime \prime}\right.$ and $23^{\circ} 12^{\prime}$ 21.35" S; 44 $5^{\prime} 39.57^{\prime \prime}$ and $44^{\circ} 22^{\prime} 33.32^{\prime \prime} \mathrm{W}$ ). This island is part of a coastal mountain range and covers $190 \mathrm{~km}^{2}$ of rough terrain (Fig. 1). Ilha Grande plays an important ecological role as a natural refuge for several Atlantic Rainforest species. There are currently 71 mammal species described for Ilha Grande State Park of which $22.3 \%$ are endemic to the Southeastern Brazilian Atlantic Rainforest (Pereira et al., 2001; Rocha et al., 2009).

Human presence on the island dates back to at least $2910 \mathrm{BC}$ (Oliveira, 2002). Over the centuries a major portion of the native vegetation was replaced by crops, mainly maize, coffee, and sugar cane. The gradual abandonment of these farming areas left a forest mosaic in different successional stages, which represent the current vegetation. Although the date of A. heterophyllus's introduction to Ilha Grande is unknown, the island was effectively settled during the $18^{\text {th }}$ century, leading to an increase in the number of ships sailing in and out of some villages (Santiago et al., 2009). It is therefore likely that jackfruit was introduced between the mid- $18^{\text {th }}$ century and the beginning of the $19^{\text {th }}$ century (Bergallo et al., 2016). 


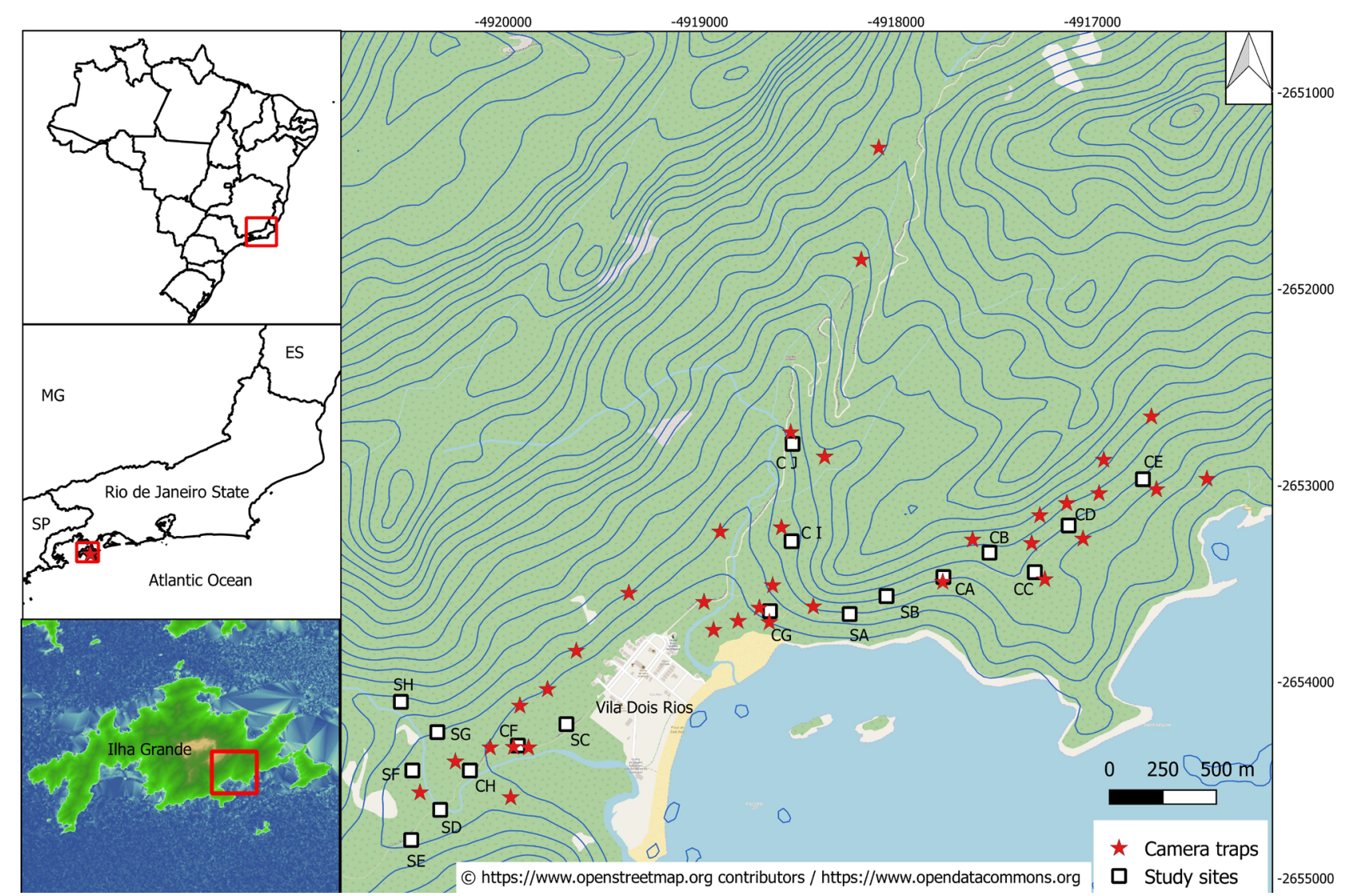

Fig. 1. Map of Ilha Grande on the southwestern coast of Rio de Janeiro state showing grids (white squares) and camera trap locations (red stars) near Vila Dois Rios, Angra dos Reis municipality, RJ, Brazil. The level lines vary 30 meters from each other.

Seed dispersal distance and camera trapping

In order to assess the seed dispersal distance and determine the predation rate two experiments were set up: (1) we tied jackfruit seeds to thread spools and measured seed dispersal distance; and (2) we used camera traps to determine consumers, predators, and potential seed dispersers.

To develop experiment 1, we looked for differences in jackfruit seed removal with and without mesocarp by animals from the study site. Six grids (CA, CC, CF, CG, CH, CI, Fig. 1) were defined in a forest area where adult jackfruit trees occur at different densities $(12,32,33,28,5,18$, respectively). Each grid covered an area of $1600 \mathrm{~m}^{2}$ with $200 \mathrm{~m}$ minimum distance between two grids (Fig. 1). We counted all jackfruits with BHD (breast height diameter) greater than or equal to $5 \mathrm{~cm}$ in the study grids. As an animal can be attracted to the grid area by food available in its surroundings, to verify the densities of jackfruits, we extended our search to within $20 \mathrm{~m}$ of the grid, from 1600 $\mathrm{m}^{2}$ to $6400 \mathrm{~m}^{2}$. Hence, the jackfruit density in each grid corresponds to the number of jackfruit trees within $6400 \mathrm{~m}^{2}$. All grids were set up in secondary forest with similar regeneration history at altitudes varying between 15 and $175 \mathrm{~m}$ above sea level. Seeds were drilled and attached to a metal wire $0.5 \mathrm{~mm}$ thick and $10 \mathrm{~cm}$ long. The tips of wires attached to jackfruit seeds were subsequently tied to the tips of thread spools to reduce the chance that rodents might sever the sewing thread with their teeth. Each spool was placed in a plastic case with a passage for the thread. The $30 \mathrm{~m}$ long spools were attached to trees approximately $1 \mathrm{~m}$ above ground while the seeds were placed directly on the ground. This methodology has been used to study secondary dispersion (e.g. Forget \& Milleron, 1991, Zimmermann et al., 2012). Six spools at least $10 \mathrm{~m}$ apart were placed inside each grid including three seeds with mesocarp and three seeds without mesocarp. These devices were checked monthly from April 2008 to March 2009 and seeds were replaced whenever removed by animals. By following the thread, we registered where the seeds had been carried to and then verified whether they were preyed on, left intact or effectively dispersed, and measured the distance from the starting point to the final point of dispersal or consumption. A total of 216 seeds with mesocarp and 216 seeds without mesocarp were utilised, 36 in each grid. 
To determine which species feed on jackfruit mesocarp and which feed on seeds (i.e. experiment $2)$, camera-traps were set up in the forest on a monthly basis from September 2008 to November 2009. We used Trapa-Câmera ${ }^{\circledR}$ infrared camera traps with a maximum resolution of eight megapixels and a viewing range between four and six meters. We ran preliminary tests photographing animals and found this procedure inadequate for our purposes. We then programmed the camera-traps to record 10 -second long videos with 10 -second intervals every time the infrared sensor was triggered at any hour of the day. The sensitivity of infrared sensors was set to the maximum in order to register small rodents. Camera-traps were attached to trees 10 $\mathrm{cm}$ above ground one day per month in points outside the previously described grids. An open $A$. heterophyllus fruit was placed one to two meters to the front of each camera. All seeds in the exposed portion of the fruit were removed and placed on the ground approximately $20 \mathrm{~cm}$ away from the fruit. The same was done the following day at different locations, resulting in a total of 37 camera-trap footages per night (Fig. 1). Mammal records from the same camera trap were considered independent records when they were taken at least one hour apart.

\section{Native seed dispersal by small mammals}

Small mammals were captured in 18 grids of $1600 \mathrm{~m}^{2}, 8$ without jackfruits and 10 with different densities of jackfruits. In each grid, we opened nine live-traps on the ground $20 \mathrm{~m}$ apart from each other, and two in understory and canopy. Each grid was opened bimonthly from October 2006 to September 2009. Faeces of the small mammals captured were collected, identified and analysed in the laboratory. The relative frequencies of each item found in the samples were calculated dividing the number of samples in which each item occurred by the total number of samples collected. Seeds found in faeces were identified in the lowest level of classification as possible.

\section{Jackfruit production}

In all the months of small mammal capture, the grids were traced by recording the amount of jackfruit with ripe fruit and the total amount of jackfruit per tree. More intense fruit production was observed from October to March. During these months $94 \%$ of sampled jackfruit trees bore fruit, while from April to September only 6\% of trees were bearing fruit.

\section{Data analysis}

The Chi-Square test was used to verify whether there were significant differences between predation and potential dispersal behaviour (Zar, 1984). Non-identified behaviour was excluded from the analysis. This test was also used to verify the difference between mesocarp and seeds consumed by mammals registered in video footage. Linear regression was used to test the hypothesis that the number of preyed seeds is dependent on the number of fruit-producing jackfruit trees, using the number of non-preyed seeds as the dependent variable. Each independent observation corresponded to the number of fruit-producing jackfruit trees in each sampled grid in the 12 months of data gathering.

The Kolmogorov-Smirnov test was used to verify whether the percentage of intact seeds in small mammal faeces were significantly different between grids (with and without jackfruits). The Linear regression test was used to verify whether there was a significant relationship between abundance of native seeds found in small mammal's faeces and abundance of jackfruits in different grids. This analysis was conducted for Didelphis aurita and T. dimidiatus, which were captured in all grids.

The taxonomy of rodents followed Patton et al (2015), marsupial and primates (Reis et al. 2006). All statistical analyses were performed in Systat Software, Inc., version 13. We conducted this study under a permanent license from Instituto Brasileiro do Meio Ambiente e dos Recursos Naturais Renováveis - IBAMA (SISBIO 12548-1).

\section{Results}

\section{Seed removal}

Among the 216 jackfruit tree seeds without mesocarp 168 were preyed on, 36 were intact and 11 dispersed. Of 216 jackfruit seeds with mesocarp, 181 were preyed on, 20 were intact, and 5 dispersed (Table 1).

No significant difference was found between frequencies of preyed seeds with and without mesocarp in the more intense fruit production period $\left(\chi^{2}=1.195, p=0.274\right)$. However, seeds with mesocarp were more preyed on than seeds without mesocarp $\left(\chi^{2}=5.400, p=0.020\right.$, Table 1$)$ in the less intense fruit production period. When both seed classes, with and without mesocarp, were analysed together a significant difference between the two fruit production periods $\left(\chi^{2}=12.97, p=0.001\right)$ was observed with higher predation values in the less intense fruit production period (Table 1). 
Table 1. Number of preyed on, intact, or not found jackfruit seeds with or without mesocarp in more or less intense fruit production periods in Ilha Grande State Park, Brazil. Chi-square and p values were obtained comparing intervals during and between fruit production periods

\begin{tabular}{lcccccc}
\hline & \multicolumn{2}{c}{ More intense fruit production } & \multicolumn{2}{c}{$\begin{array}{c}\text { Less intense fruit } \\
\text { production }\end{array}$} & $\begin{array}{c}\text { Comparison between } \\
\text { fruit production }\end{array}$ & $\begin{array}{c}\text { Seeds not } \\
\text { found }\end{array}$ \\
\hline Mesocarp & Preyed & $\chi^{2}(\mathrm{p})$ & Preyed & $\chi^{2}(\mathrm{p})$ & $\chi^{2}(\mathrm{p})$ & \\
With & 84 & $1.195(0.274)$ & 97 & 5.400 & $0.934(0.334)$ & 15 \\
Without & 81 & & 87 & $\mathbf{( 0 . 0 2 0}$ & $0.214(0.643)$ & 12 \\
Total & 165 & & 184 & & $12.970(\mathbf{0 . 0 0 1})$ & 27 \\
& & & & & \\
Mesocarp & Intact & & Intact & & $\chi^{2}(\mathrm{p})$ & \\
With & 17 & $1.195(0.274)$ & 3 & 5.400 & $9.800(\mathbf{0 . 0 0 2})$ & \\
Without & 24 & & 12 & $\mathbf{( 0 . 0 2 0}$ & $4.000(\mathbf{0 . 0 4 6})$ & \\
Total & 41 & & 15 & & $2.204(0.138)$ & \\
\hline
\end{tabular}

Upon comparing frequencies of non-preyed seeds between more and less intense fruit production periods a significant difference was observed for both seed classes without mesocarp $\left(\chi^{2}=4.000, p=0.046\right)$ and with mesocarp $\left(\chi^{2}=9.800, p=0.002\right)$. In both cases dispersal values were higher in the period of more intense fruit production (Table 1).

The majority of non-preyed jackfruit seeds was not dispersed and seeds were found untouched in their original place (31 during more intense fruit production and nine during less intense fruit production). There were only 16 dispersed seed records. Of the 10 dispersal events during more intense fruit production there were four seeds with mesocarp and six without mesocarp. Of the six dispersal events during less intense fruit production there were two seeds with mesocarp and four without mesocarp. All dispersed seeds were found in sheltered areas on the ground either under dense vegetation cover or in rock niches. Dispersal distances were similar for periods of more $(6.16 \pm 4.28 \mathrm{~m})$ and less intense fruit production $(6.05 \pm 3.99 \mathrm{~m})$.

Linear regressions between the number of nonpreyed seeds and the number of fruit producing trees were significant for grids $\mathrm{CC}\left(\mathrm{r}^{2}=0.625, \mathrm{~N}=12, \mathrm{~F}=\right.$ $6.415, \mathrm{p}=0.030), \mathrm{CG}\left(\mathrm{r}^{2}=0.623, \mathrm{~N}=12, \mathrm{~F}=6.330\right.$, $\mathrm{p}=0.031)$, and $\mathrm{CI}\left(\mathrm{r}^{2}=0.817, \mathrm{~N}=12, \mathrm{~F}=20.139\right.$, $\mathrm{p}=0.001)$. The lower values of predated seeds were associated with a higher number of fruit producing trees (Fig. 2). No significant relation was observed between number of preyed seeds and number of fruit producing trees in grids $\mathrm{CA}(\mathrm{N}=12, \mathrm{~F}=1.104$, $\mathrm{p}=0.318), \mathrm{CF}(\mathrm{N}=12, \mathrm{~F}=0.110, \mathrm{p}=0.747)$, and $\mathrm{CH}(\mathrm{N}=12, \mathrm{~F}=3.570, \mathrm{p}=0.088)$ (Fig. 2).

\section{Camera trapping records}

Seven of nine species registered by camera traps were mammals: agouti, Dasyprocta leporina (Linnaeus 1758); spotted-paca, Cuniculus paca
(Linnaeus 1766); water rat, Nectomys squamipes Brants 1827; spiny rat, Trinomys dimidiatus (Günther 1876), common opossum, Didelphis aurita (WiedNeuwied 1826); marmoset Callithrix spp.; and ninebanded armadillo Dasypus novemcinctus Linnaeus 1758. Two other species registered were a bird, the gray-necked wood-rail Aramides cajaneus (Müller 1776), and the tegu lizard, Salvator merianae (Duméril \& Bibron, 1839).

The camera traps recorded a total of 744 events. Of these, 23 camera traps recorded 293 D. aurita appearances (Fig. 3a); 20 camera traps recorded 224 T. dimidiatus appearances (Fig. 3b); 15 camera traps recorded 169 C. paca appearances (Fig. 3c); five camera traps recorded $16 \mathrm{~N}$. squamipes appearances; one camera trap recorded 18 Callithrix spp. appearances; two camera traps recorded two $D$. novemcinctus appearances; five camera traps recorded $18 \mathrm{~A}$. cajaneus appearances; and three camera traps recorded four $S$. merianae appearances. Mammal species represent $97 \%$ of all footage of which $D$. aurita, $T$. dimidiatus and $C$. paca together accounted for $92 \%$ (Fig. 4).

In both $D$. novemcinctus records, the animals were searching for arthropods in the litter around the fruit, not feeding directly on jackfruit. A group of at least five Callithrix spp. individuals fed only on mesocarp, leaving seeds intact near the fruit. In 11 of the 16 records of $N$. squamipes it was feeding on mesocarp, while in the other five we were unable to identify consumption of a specific fruit part. In nine of the 18 records of $A$. cajaneus it was feeding on mesocarp, while in the other nine it was not possible to identify specific fruit parts. In two of the four records of $S$. merianae it was feeding on mesocarp, in the other two it could not be identified. Although part of the records is indistinguishable, no direct seed consumption was observed in the footage obtained. 

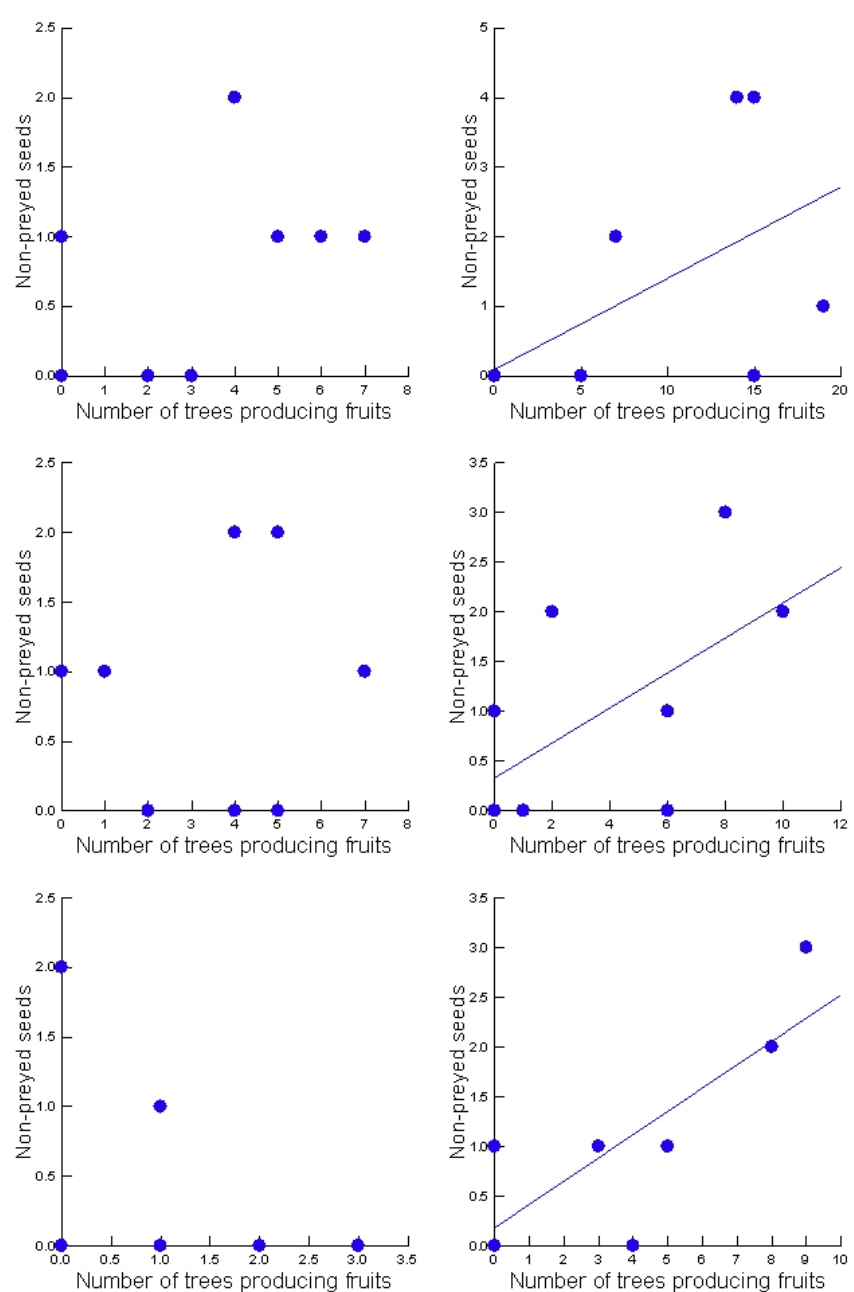

Fig. 2. Simple regression between the number of non-preyed jackfruit seeds and the amount of fruit producing trees in the grids.

Of the 293 records of $D$. aurita it was not possible to identify specific behaviour in 142 events while mesocarp consumption was observed in the remaining 151 with no straight interest in jackfruit seeds. Of the 224 footages of $T$. dimidiatus 155 were not specifically identified, 10 showed mesocarp feeding, and in the remaining 59 the animals were either preying on the fruit or carrying jackfruit seeds. Of the 169 footages of $C$. paca, 144 registered feeding on unidentified fruit parts, 10 showed mesocarp consumption, and in the remaining 15 the animals were preying on or carrying jackfruit seeds (Fig. 5). Consumption of mesocarp and seeds by $D$. aurita and T. dimidiatus $\left(\chi^{2}=\right.$ $176.46, \mathrm{p}=0.001)$ were significantly different between these species as well as between $D$. aurita and C. paca $\left(\chi^{2}=102.44, \mathrm{p}=0.001\right)$, and between T. dimidiatus and C. paca $\left(\chi^{2}=7.14\right.$, p $=0.012$ ). Seed predation and potential dispersal did not vary between $T$. dimidiatus and $C$. paca $\left(\chi^{2}=0.160, p=0.855\right)$ (Fig. 5).
Native seed dispersal by small mammals

We recorded 11 species of small mammals $(<2$ $\mathrm{kg}$ ) in live traps and collected 681 samples of faeces, 22 of which being of Guerlinguetus brasiliensis, 36 of Euryoryzomys russatus, 30 of Nectomys squamipes, 19 of Oxymycterus dasytrichus, 26 of Rhipidomys itoan, 383 of Trinomys dimidatus, 132 of Didelphis aurita, 3 of Gracilinanus microtarsus, 22 of Marmosops incanus, 4 of Monodelphis americana and 4 of Callithrix spp. (Appendix). The percentage of destroyed and intact native seeds in faeces varied among species of small mammals. Didelphis aurita and E. russatus were the species with the highest percentage of intact seeds, while $T$. dimidiatus and $O$. dasytrichus had the highest percentage of destroyed seeds in faeces (Table 2).
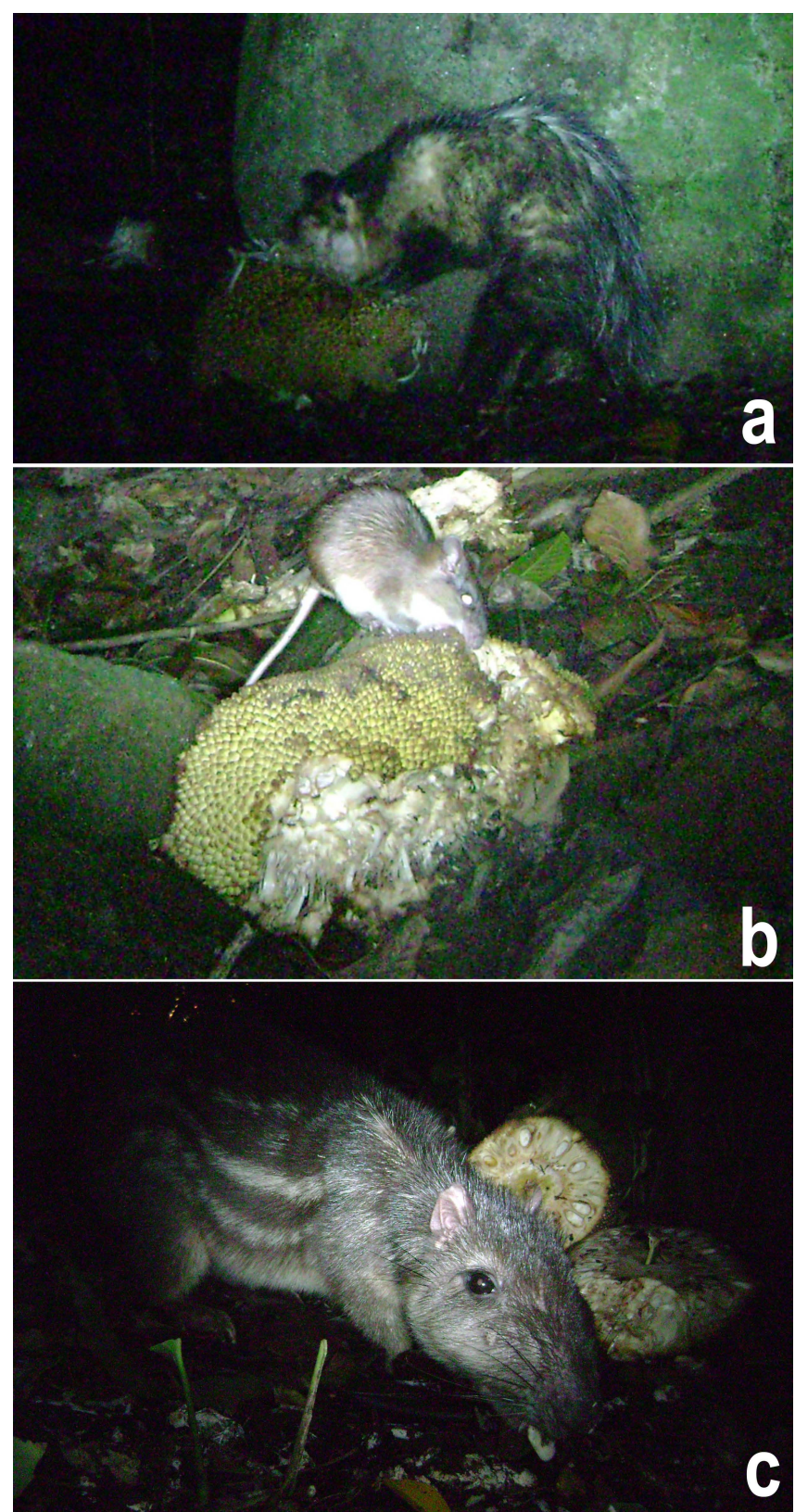

Fig. 3. a - Common-opossum, Didelphis aurita; b - Spinyrat, Trinomys dimidiatus and $\mathrm{c}$ - Spotted-paca, Cuniculus paca consuming jackfruit. 


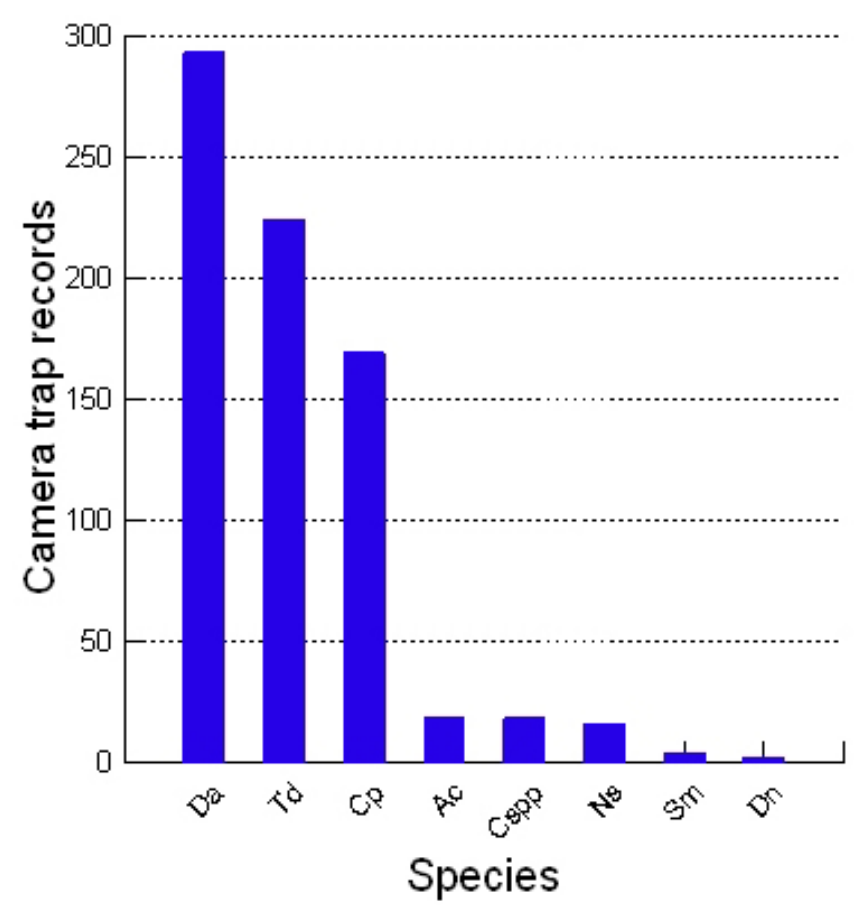

Fig. 4. Number of records by camera traps for Didelphis aurita (Da); Trinomys dimidiatus (Td); Cuniculus paca (Cp); Aramides cajaneus (Ac); Callithrix spp. (Cspp); Nectomys squamipes (Ns); Salvator merianae (Sm) and Dasypus novemcinctus (Dn).

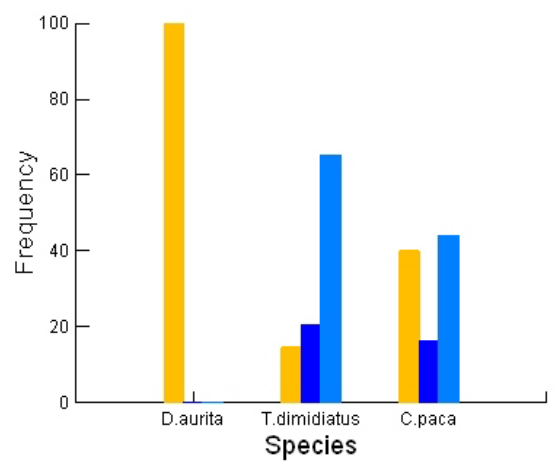

Mesocarp Consumption - Seed consumption Seed dispersion

Fig. 5. Frequencies of mesocarp, seed consumption and seed dispersal by Didelphis aurita, Trinomys dimidiatus and Cuniculus paca.
The percentage of intact seeds in faeces varied in small mammals between grids with and without jackfruit trees (Fig. 6). Didelphis aurita, E. russatus and $T$. dimidiatus had almost the same percentage of intact seeds in both grids, but for $G$. brasiliensis and $N$. squamipes, intact seeds were frequently found in grids without jackfruit (Fig. 6). Hence, there were no differences in the percentage of intact seeds in faeces between grids considering all species together $(\mathrm{KS}=0.524, \mathrm{p}=0.280)$.

The abundance of native seeds found in $D$. aurita and $T$. dimidiatus faeces varied among the grids with different abundance of jackfruit trees (Fig. 7). The abundance of native seeds in the faeces of $D$. aurita decreased significantly from grids without jackfruit trees to grids with jackfruit trees $\left(\mathrm{N}=18, \mathrm{r}^{2}=0.490, \mathrm{~F}=5.046\right.$, $\mathrm{p}=0.039$ ). However, the relationship was not significant for $T$. dimidiatus $\left(\mathrm{N}=18, \mathrm{r}^{2}=0.030\right.$, $\mathrm{F}=0.492, \mathrm{p}=0.492)$.

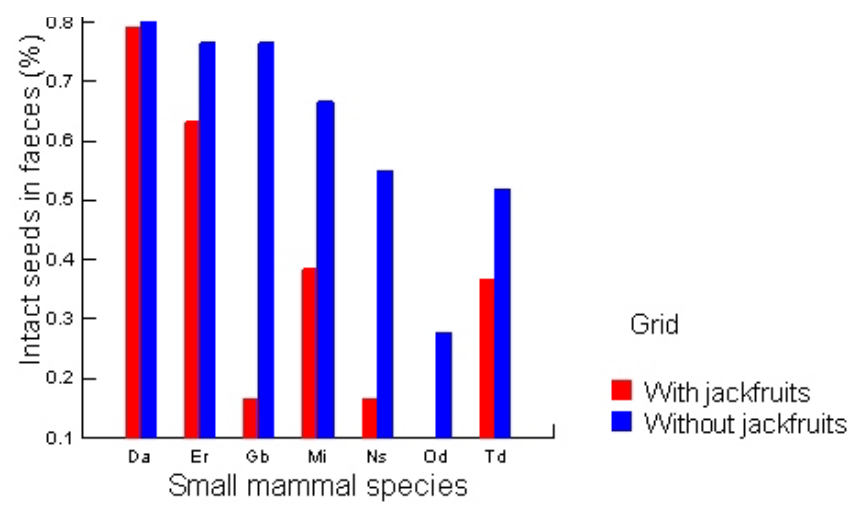

Fig. 6. Percentage of intact native seeds found in faeces of small mammals in grids with and without jackfruit trees at Ilha Grande State Park, Brazil. Legend: Da-Didelphis aurita, $\mathrm{Er}$ - Euryoryzomys russatus, Gi - Guerlinguetus brasiliensis, $\mathrm{Mi}$ - Marmosops incanus, Ns - Nectomys squamipes, Od Oxymycterus dasythricus and $\mathrm{Td}$ - Trinomys dimidiatus.

Table 2. Percentage of destroyed and intact native seeds found in small mammal faeces, the Chi-square value $\left(\chi^{2}\right)$ and $p$ value. The table is arranged in descending order of potential for native seed dispersal

\begin{tabular}{|l|c|c|c|c|}
\hline Species & $\%$ Destroyed seeds & $\%$ Intact seeds & $\chi^{2}$ value & P \\
\hline Didelphis aurita & 20.46 & 79.54 & 46.091 & $<0.001$ \\
\hline Euryoryzomys russatus & 30.56 & 69.44 & 1.000 & 1.000 \\
\hline Marmosops incanus & 50.00 & 50.00 & 0.154 & 0.695 \\
\hline Nectomys squamipes & 53.85 & 46.15 & 0.257 & 0.612 \\
\hline Guerlinguetus brasiliensis & 54.29 & 45.71 & 11.641 & 0.001 \\
\hline Trinomys dimidiatus & 58.44 & 41.56 & 3.556 & 0.059 \\
\hline Oxymycterus dasythricus & 72.22 & 27.78 & & 0.020 \\
\hline
\end{tabular}


Didelphis aurita

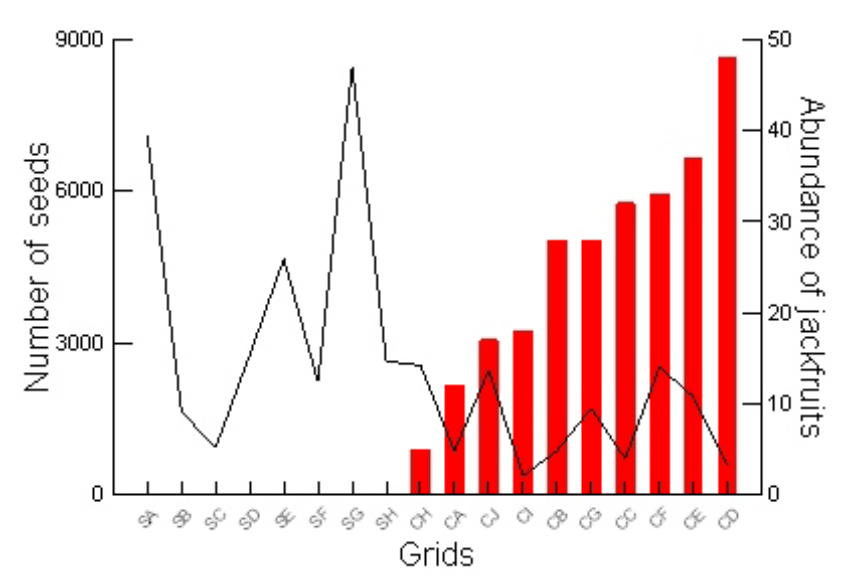

Trinomys dimidiatus

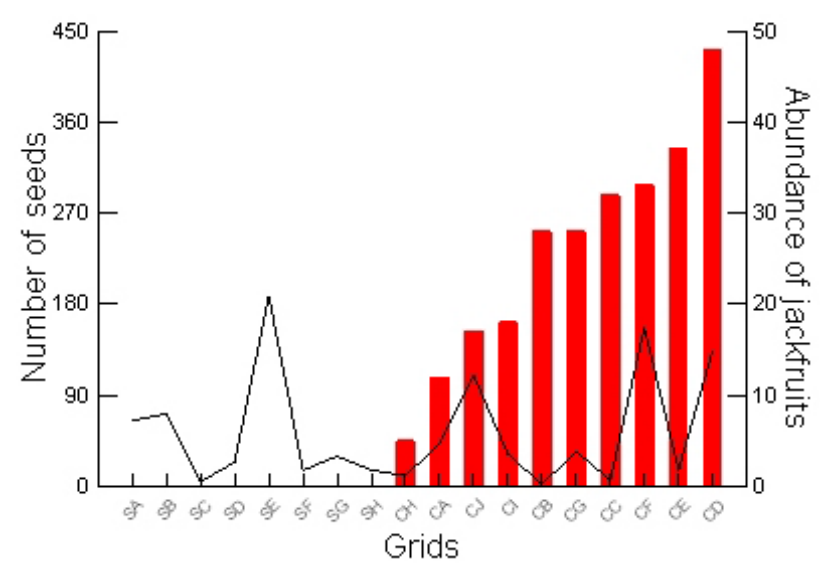

Fig. 7. Number of seeds found in faeces (line) of Didelphis aurita and Trinomys dimidiatus, in each grid with different jackfruit abundances (bars). Grids beginning with $\mathrm{S}$ are those without jackfruit.

\section{Discussion}

Our camera-trap records revealed that of the nine vertebrate-jackfruit interactions at Ilha Grande State Park, five involved mammal species. Jackfruit trees are also exposed to interactions with greater spearnosed bats Phyllostomus hastatus (Raíces et al., 2008), squirrels Guerlinguetus brasiliensis, black-horned capuchin monkeys Sapajus nigritus, and orange-spined hairy dwarf porcupines Coendou villosus (pers. obs.).

Seeds with mesocarp were more preyed on than seeds without mesocarp. One possible explanation is that since jackfruit mesocarp has a strong and very characteristic odour (Elevitch \& Manner, 2006; Jagadeesh et al., 2007) it may attract nocturnal mammals such as rodents and marsupials which have a heightened sense of smell (Barnett, 1975; Atramentowicz, 1982). Our results suggest that seeds without mesocarp should have higher survival rates when compared with seeds still attached to the fruit, which would be more easily detected by predators.
Predation rates of both seeds with and without mesocarp were higher during less intense fruit production periods. This might be due to fruit density at the peak production period being 77 times higher than fruit density during the less intense fruit production period. Also, although the abundance of some rodent species, mainly $T$. dimidiatus, was higher in areas where jackfruit trees are present (Mello et al., 2015), there was no significant increase in this species density at the peak of fruit production. Consequently, when there are more food resources available at the peak of jackfruit production seed predation is lower. Our results do not agree with previous studies such as Pizo \& Vieira (2004), who found predation rates of native Euterpe edulis palms by generalist rodents not to be dependent on plant density. However, we believe that because jackfruit trees occur in high density (Abreu \& Rodrigues, 2010; Bergallo et al. 2016), and because the fruit is one of the largest of all tree species (Elevitch \& Manner, 2006) the number of fruits and consequently seed availability surpass mammal consumption capacity during more intense fruit production periods. This is corroborated by the fact that adult jackfruit density was high in the three grids and seed predation was low during more intense fruit production periods.

Another important aspect related to predation is that insect larvae were not found (e.g. Coleoptera or Lepidoptera larvae) in jackfruit seeds, which would be expected for large seeds in tropical forests (Sari \& Ribeiro-Costa, 2005; Scherer \& Romanowski, 2005; Silva et al., 2007; Andreazzi et al., 2011; Dracxler et al., 2011). We believe there has not been enough ecological time yet to allow insects to adapt to and use jackfruit seeds in invaded areas.

Although jackfruit dispersal is predominantly barochoric in the Atlantic forest leading to high rates of seed clumping below the mother-tree (Abreu \& Rodrigues, 2010) we observed that sinzoochory by mammals also occurred. This result corroborates the findings of Novelli et al. (2010) who performed experiments on barochoric dispersal of $A$. heterophyllus on sloping terrain. These authors did not observe differences between the number of seeds found downhill and uphill from the mother plant, which suggested that secondary dispersers may play an important role in the dispersal of jackfruit in the Atlantic forest.

Our experiment with seeds tied to spools showed that dispersal distance is short with mean values of six meters. This short distance may however be enough for some seeds to escape effects the mother plant may have over seedlings as well as high seed density below the mother plant, therefore increasing the dispersed 
propagules' chances of survival. Although the maximum distance of seed dispersal was 15 meters, they were carried over $20 \mathrm{~m}$ in six events when seeds were preyed on, and in one event a seed was carried for 55.5 meters. This suggests that $A$. heterophyllus seeds may be carried to farther distances from the mother plant. Even though long distance dispersal does not seem to occur frequently, this may help jackfruit reach new areas. In our experiment only 432 seeds were controlled, a low number considering a single fruit may bear up to 500 seeds (Elevitch \& Manner, 2006).

Our camera trap records showed that Didelphis aurita, Cuniculus paca, and Trinomys dimidiatus are the main jackfruit consumers in Ilha Grande, of which only $C$. paca and $T$. dimidiatus were filmed preying on seeds. It was not clear whether $C$. paca disperses jackfruit seeds as the species behaviour was affected by the camera traps' led lamps. When the lights came on most individuals fled the area in the first few seconds of the footage. This was the main reason for the high events of unidentified feeding behaviour in our analyses on jackfruit parts. This also influenced the number of seeds carried by agoutis which carried jackfruit seeds or fruit parts to feed on out of the camera light range. On the contrary, D. aurita and $T$. dimidiatus did not seem to be bothered when the camera lights came on, staying in front of the lamps in most of the records. Artocarpus heterophyllus seed dispersal is probably more frequently attained by $T$. dimidiatus. Mileri et al. (2012) observed two species of mammals feeding on jackfruit seeds in Duas Barras Biological Reserve in Brazil, Dasyprocta leporina and Trinomys paratus. But only $T$. paratus was recorded with seeds in its mouth (Mileri et al., 2012).

The small mammals played an important role in the dispersion of native seeds. Oxymycterus dasythricus was the species with the highest percentage of native seeds destroyed $(72 \%)$, but species of this genus are preferably insectivorous (Reis et al., 2006) and yet they have the potential to disperse seeds. Didelphis aurita and E. russatus, are the species with the highest potential for dispersion of native seeds ( $80 \%$ and $70 \%$ respectively), and intact seeds were found about same proportion for both species in grids with and without jackfruit. Guerlinguetus brasiliensis, N. squamipes and $M$. incanus keep about $50 \%$ of their seeds intact in faeces. Trinomys dimidiatus is not a good disperser of native seeds because more than half of the seeds in its faeces are destroyed.

Of all the species observed consuming jackfruit, the two rodents $T$. dimidiatus and $C$. paca seem to have key roles in seed dispersal and predation. The opossum, D. aurita seems to consume only fruit mesocarp which suggests that this species may not play an important role in such processes. One jackfruit seed was found once in D. aurita faeces (pers. obs.). We think that this must however be seen as an exception, as most jackfruit seeds are too large to be swallowed by opossums. However, the role of $D$. aurita as native seed disperser in the Atlantic Forest has already been observed by other authors (Caceres \& Monteiro-Filho, 2000). Our study clarifies this role and shows the impact of the high abundances of jackfruit for the regeneration of the forest, since the amount of native seeds in D. aurita faeces decreased consistently in areas with jackfruit. This may be due to two non-exclusive hypotheses: a greater consumption of jackfruit or a lower availability of fruits of native species in areas with jackfruit.

In conclusion, mammals are playing a negative role in the natural restoration of the forest, helping to expand jackfruit tree dispersal, and this is occurring in different ways by distinct mammal species. The greatest impacts are the loss of the role of $D$. aurita as native seed disperser in areas with a great abundance of jackfruit and the role acquired by $C$. paca and $T$. dimidiatus as dispersers of jackfruit seeds. Measures to control expansion of the jackfruit and allow restoration are necessary. However, as jackfruit has become an important resource for mammals, any control measure will have to consider the impact of its withdrawal on mammals that consume its fruits.

\section{Acknowledgements}

We thank CEADS/UERJ for logistics support. We also thank Natália Ardente, Luiza Santos, Wagner Silva, Júlia Lins Luz, Thiago Modesto, Flávia Pessôa, Tássia Jordão Nogueira and Hermano Albuquerque for all field assistance. We thank Henrique B. Rocha for the English revision. Dr. Alexandra Pires and Dr Silvia Ziller gave an important improvement to the manuscript. DSLR and JHM received a doctoral and master grant, respectively, from FAPERJ during this study. PMF received an undergraduate grant from CNPq. HGB thanks scientific productivity grants from CNPq (307715/2009-4; 307781/2014-3), Cientista do Nosso Estado from FAPERJ (E26/102.799/2008; E26 /201.267/2014) and Prociência UERJ.

\section{References}

Abreu R.C.R., Rodrigues P.J.F.P. 2010. Exotic tree Artocarpus heterophyllus (Moraceae) invades the Brazilian Atlantic Rainforest. Rodriguésia 61(4): 677-688.

Aizen M.A., Morales C.L., Morales J. 2008. Invasive mutualists erode native pollination webs. PLoS Biology 6(2): 396-403. DOI: 10.1371/journal.pbio.0060031

Andreazzi C.S., Pimenta C.S., Pires A.S., Fernandez F.A.S., Oliveira-Santos L.G.R., Menezes J.F.S. 2011. Increased productivity and reduced seed predation favor a 
large-seeded palm in small Atlantic Forest fragments. Biotropica 43: 1-8. DOI: 10.1111/btp.12012

Asquith N.M., Wright S.J., Clauss M.J. 1997. Does mammal community composition control recruitment in neotropical forests? Evidence from Panama. Ecology 78(3): 941-946.

Atramentowicz M. 1982. Influence du milieu sur I' activité locomotrice et al reproduction de Caluromys philander. Revued'Ecologie (Terre et al Vie) 36: 373-395.

Barnett S.A. 1975. The rat: A study in behavior. Chicago: University of Chicago Press. 318 p.

Bergallo H.G., Bergallo A.C., Rocha H.B., Rocha C.F.D. 2016. Invasion by Artocarpus heterophyllus (Moraceae) in an island in the Atlantic Forest Biome, Brazil: distribution at the landscape level, density and need for control. Journal of Coastal Conservation 20(3): 191198. DOI: 10.1007/s11852-016-0429-9

Caceres N.C., Monteiro-Filho E.L. 2000. The common opossum, Didelphis aurita, as a seed disperser of several plants in southern Brazil. Ciência e Cultura 52(1): 41-44.

Connell J.H. 1971. On the role of natural enemies in preventing competitive exclusion in some marine animals and in the rain forest trees. In: P.J. den Boer, G.R. Gradwell (Eds): Dynamics of populations. Wageningen, Netherlands: Centre for Agriculture Publications and Documentation. P. 298-310.

Corlett R.T. 1998. Frugivory and seed dispersal by vertebrates in the Oriental (Indomalayan) Region. Biological Reviews of the Cambridge Philosophical Society 73(4): 413-448.

D’Antonio C.M., Vitousek P.M. 1992. Biological invasions by exotic grasses, the grass/fire cycle and global change. Annual Review of Ecology and Systematics 23: 63-87.

Davidar P. 1987. Fruit structure in two neotropical mistletoes and its consequences for seed dispersal. Biotropica 19: 137-139.

Davis M.A., Grime J.P., Thompson K. 2000. Fluctuating resources in plant communities: a general theory of invasibility. Journal of Ecology 88: 528-534. DOI: 10.1046/j.1365-2745.2000.00473.x

DeWalt S.J., Denslow J.S., Ikes K. 2004. Natural-enemy release facilitates habitat expansion of the invasive tropical shrub Clidemia hirta. Ecology 85(2): 471-483.

Dracxler C.M., Pires A.S., Fernandez F.A.S. 2011. Invertebrate Seed Predators are not all the Same: Seed Predation by Bruchine and Scolytine Beetles Affects Palm Recruitment in Different Ways. Biotropica 43: 8-11. DOI: 10.1111/j.1744-7429.2010.00723.x

Elevitch C.R., Manner H.I. 2006. Artocarpus heterophyllus (jackfruit), ver. i.iv. In: C.R. Elevitch (Ed.): Species Profiles for Pacific Island Agroforestry, Permanent Agriculture Resources (PAR). Holualoa, Hawaii. Available from: http://www.traditionaltree.org.

Forget P.M., Milleron T. 1991. Evidence for secondary seed dispersal by rodents in Panama. Oecologia 87, 596-599.

Galetti M., Pizo M.A., Morellato P.C. 2003. Fenologia, frugivoria e dispersão de sementes. In: L. Cullen Jr., R. Rudran, C. Valladare-Padua (Eds.): Métodos de estudos em biologia da conservação e manejo da vida silvestre. Curitiba: UFPR; Fundação o Boticário de Proteção á natureza. P. $395-422$.
Galetti M. 2004. Parques do Pleistoceno: recriando o Cerrado e o Pantanal com a megafauna. Natureza \& Conservação 2(1): 1-16.

Galetti M., Donatti C.I., Pires A.S., Guimarães P.R., Jordano P. 2006. Seed survival and dispersal of an endemic Atlantic forest palm: the combined effects of defaunation and forest fragmentation. Botanical Journal of the Linnean Society 151: 141-149.

Godagama W.K., Wermmer C., Ratnasooriya W.D. 1999. The diet of Sri Lanka domesticated elephant (Elephas maximus maximus). Vidyodaya Journal of Science 1(8): 75-85.

Janzen D.H. 1970. Herbivores and the number of tree species in tropical forests. American Naturalist 104: 501-528.

Janzen D.H., Martin P.S. 1982. Neotropical anachronisms: the fruits the gomphoteres ate. Science 215: 19-27.

Jagadeesh S.L., Reddy B.S., Swamy G.S.K., Raghavan G.S.V. 2007. Chemical composition of jackfruit (Artocarpus heterophyllus Lam.) selections of Western Ghats of India.College of Horticulture, Arabhavi-591 310, UAS, Dharwad, India. Food Chemistry 102: 361-365.

Jothish P.S. 2013. Frugivory and seed dispersal of woody species by the Asian elephant (Elephas maximus) in a mid-elevation tropical evergreen forest in India. Journal of Tropical Ecology 29: 181-185.

Keane R.M., Crawley M.J. 2002. Exotic plant invasion and the enemy release hypothesis. Trends in Ecology \& Evolution 17: 164-170.

Khan M.L. 2004. Effects of seed mass on seedling success in Artrocarpus heteroplyllus L., a tropical tree species of north-east. India Acta Oecologica 25: 103-110.

Mello J.H.F., Moulton T.P., Raíces D.S.L., Bergallo H.G. 2015. About rats and jackfruit trees: modeling the carrying capacity of a Brazilian Atlantic Forest spinyrat Trinomys dimidiatus (Günther, 1877) -Rodentia, Echimyidae- population with varying jackfruit tree (Artocarpus heterophyllus L.) abundances. Brazilian Journal of Biology 75(1): 208-215.

Mello M.A.R., Shittini G.M., Selig P., Bergallo H.G. 2004. Seasonal variation in the diet of the bat Carollia perspicilata (Chiroptera: Plyllostomidae) in an Atlantic Forest area in southeastern Brazil. Publications Scientifiques du Muséum national d'Histoire naturelle 68(1): 49-55.

Mileri M., Passamani M., Eutrópio F., Oliveira A. 2012. Removal of Seeds of Exotic Jackfruit Trees (Artocarpus heterophyllus, Moraceae) in Native Forest Areas with Predominance of Jackfruit Trees in the Duas Bocas Biological Reserve, Southeastern Brazil. International Journal of Ecosystem 2(5): 93-98.

Novelli F.Z., Moreira R.P.G., Duca C., Silva A.G. 2010. O papel da barocoria na estruturação da população da jaqueira, Artocarpus heterophyllus Lam. na Reserva Biológica de Duas Bocas, Cariacica, Espírito Santo. Natureza online 8(2): 91-94.

Ojasti J. 2001. Estudio sobre el estado actual de las especies exóticas. Caracas, Venezuela: Biblioteca Digital Andina. 220 p.

Olesen J.M., Eskildsen L.I., Venkatasamy S. 2002. Invasion of pollination networks on oceanic islands: importance of invader complexes and endemic super generalists. Diversity and Distributions 8(3): 181-192. 
Oliveira R.R. 2002. Ação antrópica e resultantes sobre a estrutura e composição da Mata Atlântica na Ilha Grande, RJ. Rodriguésia 53(82): 33-58.

Patton J.L., Pardiñas U.F.J., D'Elía G. 2015. Mammals of South America. Vol. 2: Rodents. Chicago: University of Chicago Press. 1384 p.

Pereira L.G., Torres S.E.M., Silva H.S., Geise L. 2001. Nonvolant mammals of Ilha Grande and adjacent areas in Southern Rio de Janeiro State, Brazil. Boletim do $\mathrm{Mu}$ seu Nacional 459: 1-15.

Pizo M.A., Vieira E.M. 2004. Extinção de palmito afeta a predação de sementes de Euterpe edulis, uma palmeira ameaçada de Mata Atlântica. Brazilian Journal of Bio$\operatorname{logy}$ 64(3b): 669-676.

Prenter J., MacNeil C., Dick J.T., Dunn A.M. 2004. Roles of parasites in animal invasions. Trends in Ecology and Evolution 19(7): 385-390.

Raíces D.S.L., Pessôa F.S., Luz J.L., Jordão-Nogueira T., Esbérard C.E.L., Bergallo H.G. 2008. Feeding behaviour of the bat Phyllostomus hastatus (Pallas 1767) in jackfruit Artocarpus heterophyllus Lamarck (Moraceae), in Ilha Grande, Rio de Janeiro State, Brazil. Revista Brasileira de Zoociências 10(3): 265-267.

Rejmánek M., Richardson D.M. 1996. What attributes make some plant species more invasive? Ecology 77: 1655-1661.

Reis N.R., Peracchi A.L., Pedro W.A., Lima I.P. (Eds.). 2006. Mamíferos do Brasil. Londrina: Universidade Estadual de Londrina. 437 p.

Rocha C.F.D., Bergallo H.G., Alves M.A.S., Van Sluys M., Mazzoni R., Santos S.B. 2009. Fauna de ambientes interiores. In: M. Bastos, C.H. Callado (Eds.): O Ambiente da Ilha Grande. Rio de Janeiro: Universidade do Estado do Rio de Janeiro, Centro de Estudos Ambientais e de Desenvolvimento Sustentável. P. 163-245.

Santiago A.M., Guimarães C., Nogueira I., Santos M.S., Sant'anna T. 2009. História da Ilha Grande e Patrimô- nio cultural material e imaterial. In: M. Bastos, C.H. Callado (Eds.): O Ambiente da Ilha Grande. Rio de Janeiro: Centro de Estudos Ambientais e Desenvolvimento Sustentável, CEADS. P. 299-365.

Sari L.T., Ribeiro-Costa C.S. 2005. Predação de sementes de Senna multijuga (Rich.) H.S. Irwin \& Barneby (Caesalpinaceae) por bruquíneos (Coleoptera: Chrysomelidae). Neotropical Entomology 34(3): 521-525.

Scherer K.Z., Romanowski H.P. 2005. Predacão de Megacerusbaeri (Pic. 1934) (Coleoptera: Bruchidae) sobre sementes de Ipomoea imperati (Convolvulaceae), na praia da Joaquina, Florianópolis, sul do Brasil. Biotemas 18: 39-55.

Silva F.R., Begnini R.M., Scherer K.Z., Lopes B.C., Castellani T.T. 2007. Predação de Sementes de Syagrus romanzoffiana (Cham.) Glassman (Arecaceae) por Insetos na Ilha de Santa Catarina, SC. Revista Brasileira de Biociências 5(1): 681-683.

Vieira E.M., Pizo M.A., Izar P. 2003. Fruit and seed exploitation by small rodents of the Brazilian Atlantic forest. Mammalia 67(4): 1-7.

Vijaya J. 1982. Rediscovery of the Forest Cane Turtle (Heosemys silvatica) of Kerala. Hamadryad 7: 2-3.

Williamson M., Fitter A. 1996a. The varying success of invaders. Ecology 77(6): 1661-1666.

Williamson M., Fitter A. 1996b. The characters of successful invaders. Biological Conservation 78: 163-170.

Zar J.H. 1984. Biostatistical analysis. 2nd. Prentice Hall USA. 719 p.

Zenni R.D., Ziller S.R. 2011. An overview of invasive plants in Brazil. Revista Brasileira de Botânica 34: 431-446.

Zimmermann T.G., Begnini R.M., Castellani T.T., Lopes B.C., Reis A. 2012. Consumo e dispersão secundária de sementes de Mucuna urens (Fabaceae) em Floresta Atlântica no Sul do Brasil. Rodriguésia 63(4): 1139-1145.

Appendix. Number of intact seeds found in the faeces (in brackets the first number represents the number of faeces with intact seeds and the other, the total number of faeces sampled) of 11 species of small mammals captured in live traps in grids with and without jackfruits at Ilha Grande State Park. More intense jackfruit production occurs from October to March and the less intense between April and September

\begin{tabular}{|c|c|c|c|c|c|}
\hline & \multicolumn{2}{|c|}{ With jackfruit } & \multicolumn{2}{|c|}{ Without jackfruit } & \multirow[b]{2}{*}{ Total } \\
\hline & $\begin{array}{c}\text { More intense } \\
\text { fruit production }\end{array}$ & $\begin{array}{l}\text { Less intense } \\
\text { fruit production }\end{array}$ & $\begin{array}{l}\text { More intense } \\
\text { fruit production }\end{array}$ & $\begin{array}{c}\begin{array}{c}\text { Less intense fruit } \\
\text { production }\end{array} \\
\end{array}$ & \\
\hline \multicolumn{6}{|l|}{ Rodent } \\
\hline Guerlinguetus brasiliensis Gmelin, 1788 & $35(1-6)$ & $123(2-12)$ & $49(2-3)$ & $72(1-1)$ & $279(6-22)$ \\
\hline Euryoryzomys russatus (Wagner, 1848) & $4(2-6)$ & $46(10-13)$ & $172(5-7)$ & $164(8-10)$ & $386(25-36)$ \\
\hline Nectomys squamipes (Brants, 1827) & $-(0-5)$ & $3(1-5)$ & $165(5-8)$ & $395(6-12)$ & $563(12-30)$ \\
\hline Oxymycterus dasytrichus (Schinz, 1821) & $-(0-1)$ & - & $4(1-7)$ & $74(4-11)$ & $78(5-19)$ \\
\hline $\begin{array}{l}\text { Rhipidomys itoan Costa, Geise, Pereira and } \\
\text { Costa, } 2011\end{array}$ & $8(3-9)$ & $185(7-8)$ & $11(1-4)$ & $90(3-5)$ & 294(14-26) \\
\hline Trinomys dimidiatus (Günther, 1876) & $54(27-145)$ & $506(65-116)$ & $121(26-71)$ & $295(38-51)$ & $972(156-383)$ \\
\hline \multicolumn{6}{|l|}{ Marsupial } \\
\hline Didelphis aurita (Wied-Neuwied, 1826) & $909(18-28)$ & $13,645(39-44)$ & $10,827(28-29)$ & $19,642(20-31)$ & $45,023(115-132)$ \\
\hline Gracilinanus microtarsus (Wagner, 1842) & $3(1-1)$ & $95(1-1)$ & - & $7(1-1)$ & $105(3-3)$ \\
\hline Marmosops incanus (Lund, 1840) & $3(3-6)$ & $217(2-7)$ & $32(2-2)$ & $93(4-7)$ & $345(12-22)$ \\
\hline Monodelphis americana (Müller, 1776) & $0(0-1)$ & - & - & $-(0-3)$ & $-(0-4)$ \\
\hline \multicolumn{6}{|l|}{ Primates } \\
\hline Callithrix spp. & - & $344(2-2)$ & $19(1-1)$ & $2(1-1)$ & $363(4-4)$ \\
\hline
\end{tabular}


УЛЫБНИТЕСЬ, ВЫ НА КАМЕРЕ ИЛИ В ЖИВОЙ ЛОВУШКЕ!

РОЛЬ МЛЕКОПИТАЮЩИХ В РАСПРОСТРАНЕНИИ

СЕМЯН ДЖЕКФРУТА И МЕСТНЫХ ВИДОВ РАСТЕНИЙ

В ГОСУДАРСТВЕННОМ ПАРКЕ ИЛЬЯ-ГРАНДЕ (БРАЗИЛИЯ)

\author{
Д. С. Л. Райсез ${ }^{1}$, П. М. Феррейра², Х. Х. Ф. Мелло ${ }^{3}$ Х. Г. Бергалло ${ }^{4}$ \\ ${ }^{1}$ Институт по сохранению биоразнообразия имени Чико Мендеса, Бразилия \\ e-mail:danielraices@icmbio.gov.br \\ ${ }^{2}$ Центр экологии и мониторинга окружающей среды, Бразилия \\ e-mail: paulamf84@gmail.com \\ ${ }_{3}^{3}$ Федеральный университет Рио-де-Жанейро, Бразилия \\ e-mail:mello.jhf@gmail.com \\ ${ }^{4}$ Университет штата Рио-де-Жанейро, Бразилия \\ e-mail:nena.bergallo@gmail.com
}

Чужеземный вид Artocarpus heterophyllus (джекфрут), происходящий из Индии, был завезен в Бразилию в колониальный период и стал инвазионным в некоторых районах атлантических лесов. Его плоды могут весить 35 кг и содержат до 500 семян каждый. В пределах естественного ареала они распространяются черепахами, грызунами, обезьянами, дикими свиньями и слонами. Целью данного исследования было изучить влияние животных на хищничество и распространение семян джекфрута, а также влияние инвазионного растения на распространение аборигенных растений млекопитающими в государственном парке Илья-Гранде (Юго-Восточная Бразилия). Семена с мезокарпом и без него были привязаны к катушкам ниток и проверены на хищничество и распространение семян в 37 локациях. Мы обнаружили поедание мезокарпа или семян джекфрута на видео. Было зарегистрировано шесть видов млекопитающих, питающихся джекфрутом, но 92\% всех случаев пришлось на Trinomys dimidiatus, Didelphis aurita и Cuniculus paca. Cuniculus paca и Trinomys dimidiatus питались семенами и распространяли их, тогда как Didelphis aurita только питалась мезокарпом. Семена с мезокарпом поедались животными чаще, чем семена без мезокарпа, и его потребление было ниже в период более интенсивного плодообразования. Следовательно, плодообразование джекфрута может превышать способность млекопитающих потреблять его семена в районах, где плотность джекфрута высока. Фекалии мелких млекопитающих были собраны в областях с (10 ячеек карты) и без джекфрута (8 ячеек карты) и затем были проанализированы на наличие в них семян аборигенных растений. Двенадцать мелких млекопитающих были зарегистрированы в районах с джекфрутом и без него, но фекалии были собраны только для 11 видов. Didelphis aurita распространяла пропорционально больше семян аборигенных растений в области без джекфрута по сравнению с областью, где произрастал инвазионный вид. Наши результаты показали, что млекопитающие играют отрицательную роль, помогая рассеивать деревья джекфрута, что происходит разными путями в зависимости от видов млекопитающих.

Ключевые слова: Artocarpus heterophyllus, Cuniculus paca, Didelphis aurita, Trinomys dimidiatus, атлантические леса, инвазионный чужеземный вид, плодообразование, поедание семян, распространение семян, фотоловушка 